\title{
Global Spaces for Local Politics: An Exploratory Analysis of Facebook Ads in Spanish Election Campaigns
}

\author{
Dafne Calvo $^{1, *}$, Lorena Cano-Orón ${ }^{1}$ (D) and Tomás Baviera ${ }^{2}$ (D) \\ 1 Department of Language Theory and Communication Sciences, Faculty of Philology, Translation and \\ Communication, University of Valencia, Av. de Blasco Ibáñez, 32, 46010 Valencia, Spain; Lorena.Cano@uv.es \\ 2 Department of Economics and Social Sciences, Faculty of Business Administration and Management, \\ Universitat Politècnica de València, Camino de Vera, s/n, 46022 Valencia, Spain; tobapui@upv.es \\ * Correspondence: dafne.calvo@uv.es
}

check for

updates

Citation: Calvo, Dafne, Lorena Cano-Orón, and Tomás Baviera. 2021. Global Spaces for Local Politics: An Exploratory Analysis of Facebook Ads in Spanish Election Campaigns. Social Sciences 10: 271. https:// doi.org/10.3390/socsci10070271

Academic Editor: Andreu Casero-Ripollés

Received: 14 June 2021

Accepted: 13 July 2021

Published: 15 July 2021

Publisher's Note: MDPI stays neutral with regard to jurisdictional claims in published maps and institutional affiliations.

Copyright: (c) 2021 by the authors. Licensee MDPI, Basel, Switzerland. This article is an open access article distributed under the terms and conditions of the Creative Commons Attribution (CC BY) license (https:// creativecommons.org/licenses/by/ $4.0 /)$.

\begin{abstract}
Sponsored content on Facebook has become an indispensable tool for implementing political campaign strategies. However, in political communication research, this channel is still unexplored due to its advertising model in which only target audiences are exposed to sponsored content. The launching of the Facebook Ad Library in May 2018 can be considered a turning point in this regard, inasmuch as it now offers users direct access to ads paid for by political parties, among other advertisers. This paper analyzes some aspects of the strategies implemented by six national parties during the campaigns running up to the two general elections held in Spain in 2019, by performing an analysis on a corpus of 14,684 ads downloaded directly from the Facebook Ad Library. It also provides evidence of the different emphasis placed by the parties on sponsored content. For its part, an analysis of ad scheduling shows how the publishing of ads was stepped up as polling day approached, while also revealing the practice of posting political content way in advance of election campaigns.
\end{abstract}

Keywords: political communication; election campaign; political parties; Facebook ads; electoral advertising; 2019 Spanish general elections

\section{Introduction}

Online advertising has become increasing more relevant in election campaigns (Broockman and Green 2014; Kim et al. 2018). In this regard, Facebook stands out as one of the most influential social networking sites (Karpf 2016). For advertisers, the possibility of reaching target audiences chosen on the basis of their profiles and interests, as well as calculating ad spend very precisely, makes this advertising model extremely appealing. For these same reasons, election campaign staff incorporated this tool in their strategies, and has thus become a consolidated feature in election campaigns (Campos-Domínguez and García-Orosa 2018; Kreiss and McGregor 2018). However, for political communication researchers, this channel was still, by and large, opaque due to the fact that Facebook ads only reached intended target audiences. The few studies addressing this issue have solved this problem with the help of third parties (Ridout et al. 2021; Silva et al. 2020).

In recent years, sponsored content on social networking sites has given rise to new research questions and objectives, including issues like the ad spend of political parties and the central role now played by tech giants in new electoral contexts (Bakir and McStay 2018; Doyle 2015). Facebook has been the object of many studies addressing the need for its regulation (Dommett and Power 2019; Plantin et al. 2018), its political influence as a global power in foreign countries (Sinclair 2016) and the likelihood of disseminating misleading sponsored content (Mustafaraj and Metaxas 2017).

The use of Facebook for electoral purposes has been frequent since its launch. Political parties have posted content on this social networking site to gain visibility among the electorate on the Internet and engage and mobilize their voters online and offline 
(Koc-Michalska et al. 2021). Political organizations identify, in Facebook, valuable characteristics during electoral campaigns, such as direct communication with users, control of the content, and informality and authenticity in the interaction (Dyrby and Jensen 2012). However, these affordances are limited by the risk of negative online reputation, critical media attention, and scarce resources (Kalsnes 2016).

The role played by Facebook in election campaigns came under the global media spotlight due to the Cambridge Analytica scandal in March 2018 (Isaak and Hanna 2018; Richterich 2018; Tuttle 2018). This political consulting firm provided services that took advantage of the targeting capacities of the Facebook Ads platform. The scandal involved the fraudulent use of personal data, which was used to build powerful algorithms capable of predicting the dominant psychological traits of individual Facebook users with a very high degree of accuracy (Kosinski et al. 2013; Youyou et al. 2015). The relevance of this prediction can be regarded as being crucial in a persuasive communication context, as the messages conveyed will be much more convincing for receivers if tailored to their personality traits. So, considering the digital footprints left by Facebook users, together with the capacity for displaying ad content that matches user profiles, the powerful influence of this platform in election campaigns should not be underestimated.

As a consequence of the Cambridge Analytica scandal, in May 2018, Facebook launched its Ad Library, on which the content sponsored by political parties can be consulted by any user. This includes text, image, and video, as well as information on the spend, impressions, and scheduling of each ad. This new resource has opened up promising avenues for political communication researchers. Accordingly, the intention here is to delve into the data provided by this library in two of the first election campaigns to be affected by this new transparency policy, namely, those running up to the Spanish general elections held in May and November 2019. This question is particularly critical in Spain, where corruption polarizes the political debate and citizens demand more transparency from the parties (Pérez-Curiel et al. 2021).

The corpus, obtained directly from the Facebook Ad Library, was made up of 14,684 ads published by six Spanish national parties during the two election campaigns. As far as can be gathered from the literature, apart from the research conducted by Edelson et al. (2020), this study is among the first to have explored this information source (see also Cano-Orón et al. 2021).

The main objective here is to analyze ad spend and scheduling patterns, plus the subjects broached by the six national parties in those two election campaigns. The possibility of conjoining these three aspects should cast some light on the strategies underpinning the different emphasis placed by the political parties on advertising on Facebook during the campaigns. This research thus contributes to gain further insights into the impact of political advertising on Facebook, while providing the wherewithal to address some of the issues raised by previous researchers.

This paper is structured as follows. After discussing political advertising on Facebook and its Ad Library in more depth, the political context in which the two general elections were held in Spain in 2019 is described. Following this, the methodology employed is explained and the results are presented and discussed. Lastly, the limitations of this research are set out and several future lines of research are proposed.

\subsection{Political Advertising on Facebook}

The Internet has given rise to new forms of ad production and consumption (Doyle 2015; Kim et al. 2018; Rossini et al. 2018). As one of the driving forces behind contemporary economic growth, the Internet has contributed to the expansion and fine-tuning of marketing techniques in current media industries thanks to its capacity to extract and process big data (Fuchs 2016). Together with Google, Facebook is currently leading the field in the digital advertising industry Karpf (2016), whose revenues are based on the monetization of socialization and interaction on its platform (Sinclair 2016). 
Via the Facebook Ads platform, sponsored posts appear in users' newsfeeds. This tool offers companies the opportunity to reach "customized audiences" based on a broad set of variables including location, age, sex, marital status, interaction with other pages, business interests, and political orientation, among others (Kim et al. 2018; Kreiss and McGregor 2018). The newsfeeds of users who match the profiles selected by companies receive their sponsored posts. Facebook allows companies to record the reactions of users to those posts, thus providing them with valuable feedback about the effectiveness of the different strategies implemented by them (Dommett and Power 2019; Karpf 2018; Moore 2016).

There are two main factors that influence in the final advertising spend of a company. Facebook's auction system to post ads compels advertisers to raise the cost per ad to have more possibilities to show that ad. In addition, the individual ad cost will depend on the time period in which the ad is activated. In consequence, the final cost of an ad depends mainly on the maximum cost established by the sponsoring company, the demand of other advertisers for reaching the same user profile, and the activation period of the ad.

As with other public organizations, political parties have cottoned on to the benefits of Facebook's advertising tool (Kreiss and McGregor 2018). As could not be done otherwise, they have leveraged this extremely useful channel to reach specific audiences, especially undecided voters, with tailored messages during election campaigns (Dommett and Power 2019; Kim et al. 2018). For Facebook, such campaigns have become a significant source of revenue (Bakir and McStay 2018; Haenschen and Wolf 2019; Kreiss and McGregor 2018). In this complex scenario, some scholars have raised concerns about the power of this communication tool, which is capable of reaching specific voter profiles, as well as about Facebook's economic interests given its quasi monopolistic position (Gray et al. 2020; Plantin et al. 2018). Researchers have inquired into the steps that social media should take when fake news is distributed as sponsored content on their platforms (Bakir and McStay 2018; Mustafaraj and Metaxas 2017; Gray et al. 2020), how countries should tackle the influence of these global companies (Sinclair 2016), where the line between advertising and propaganda should be drawn (Tandoc et al. 2018), and the extent to which regulating their political use would affect the benefits that parties are currently deriving from new online campaigning techniques (Doyle 2015).

Sponsored content on Facebook is intended to reach only specific target audiences, which makes it very difficult to obtain reliable data for research purposes. Silva et al. (2020) built a database of Facebook ads posted by political parties during the 2018 Brazilian elections, with the help of 2000 volunteers. Ridout et al. (2021) examined a database of ads posted on Facebook by 24 different US Senate campaigns in 2018, created by a market intelligence firm. Their findings pointed to the strong relationship between the intended goals-including mobilization, persuasion, and crowdfunding-and the campaign stage in online political advertising. As the polling day came closer, ad scheduling became more critical. These researchers highlighted the difficulties in identifying election campaign strategies in Facebook ads, due, among other reasons, to the fact that the posting of sponsored content usually started well in advance of the campaign per se. The conclusions of both of these pioneering studies of political advertising on Facebook empirically confirmed the relevance of this channel in the field of political communication research.

The Cambridge Analytica scandal (Bennett and Gordon 2020) contributed to overcome the difficulties inherent in studying this advertising channel. One of the measures implemented by Facebook to resolve this crisis was the creation of the Facebook Ad Library, launched in May 2018, with aim of allowing the public access to posts sponsored by political parties and public organizations. In addition, Facebook provided relevant metadata about each ad: spend, the number of impressions, scheduling, and a basic profile of the target audience.

The intention behind the launching of this library was to enhance the ad platform's transparency. One of the first election calls after its launching were the general elections held in Spain on 28 April 2019, which were subsequently repeated on November 10 of the 
same year. The following section offers a brief overview of the political context in which both general elections were called.

\subsection{Political Context of the 2019 General Elections in Spain}

In the 2010s, Spanish politics underwent a profound transformation. Two issues with a bearing on this study stand out. The first was the political fragmentation at a national level. Traditionally up to 2015 there had been a two-party system, with the Spanish Socialist Workers' Party and the conservative People's Party alternating in power. Nationwide dissatisfaction with the political establishment, which began to make itself felt after the 2011 general elections, led to the emergence of two parties as real alternatives to the Spanish Socialist Workers' Party and the People's Party (Boix Palop and García 2014).

On the one hand, the left-wing party Podemos was founded in the aftermath of the 15-M protests, which called for, among other things, a politics untainted by corruption and focusing on the real problems of the citizenry (Domínguez and Giménez 2014); on the other, the influence of the center party Citizens, which had been founded in Catalonia in 2006 as a liberal-constitutional alternative to the pro-independence parties, began to be felt on the national political stage (Orriols and Cordero 2016). Following the 2015 December general elections, none of the parties with seats in Parliament were capable of forming a government, for which reason they were repeated in June 2016. The main difference in this second general election call was the coalition between two left-wing parties, Podemos and United Left, under the name of Unidas Podemos.

The new minority government, led by Mariano Rajoy of the People's Party, almost immediately ran into trouble. In October 2017, the regional government of Catalonia called a referendum for independence, which was declared illegal by the Constitutional Court. This political conflict presented a central role during Catalan elections in December of the same year (Carratalá and Palau-Sampio 2019). In June 2018, Prime Minister Rajoy was forced out of office after losing a no-confidence vote in Parliament, which was called after one of the People's Party's treasurers had been convicted of corruption ${ }^{1}$, with Pedro Sanchez of the Spanish Socialist Workers' Party, who had filed the motion, taking office. Against this backdrop, the right-wing party Vox started to take off. The general elections held on April 28, 2019, resulted in a parliament that was even more fragmented than in 2016 (Simón 2020). Five national parties won seats in Parliament: the Spanish Socialist Workers' Party, the People's Party, Unidas Podemos, Citizens, and Vox. As none of the parties were capable of forming a government, new elections were called for 10 November 2019. In accordance with Spanish electoral law, the campaign lasted eight days and electoral expenditure was cut by half. On this occasion, a coalition between Spanish Socialist Workers' Party and Unidas Podemos, with the support of handful of regional parties allowed a government to be formed (Rodon 2020; Simón 2021). Previous investigations have shown that social politics, territorial model, and economy were vital issues in the public debate during these elections (Pérez-Curiel and García-Gordillo 2020).

Along with the collapse of the two-party system in Spain, the other major issue over the past decade has been the impact of the Internet on political communication. The parties emerging during the 2010s have gone to greater lengths to gain visibility on social media, since this has allowed them to circumvent the mainstream media in order to engage the electorate directly (Gerbaudo 2019). All the Spanish parties deployed a wide range of digital tools in their 2015 and 2016 general election campaigns (Dader and Campos-Domínguez 2017; López-García and Valera-Ordaz 2017). The automated dissemination of messages and big data analysis techniques were incorporated in the electoral toolkit, in which audience segmentation had become a prime strategy (Campos-Domínguez and García-Orosa 2018; Anonymized).

From a digital communication perspective, the campaigns running up to the two 2019 general elections were the first in Spain in which sponsored content posted by political parties on Facebook could be audited. Accordingly, the aim of this study is to shed light on the use of the Facebook Ad platform by the main Spanish political parties during those 
two campaigns, in an initial attempt to identify the strategies that they implemented in this respect. Given the novel nature of this research, the focus is placed on basic issues, paying special attention to ad spend and its relationship with the topics addressed in the Facebook ads. To this end, the following research questions (hereinafter RQ) were formulated:

- Research Question 1: Were there any differences in Facebook ad spend among the main parties during the two 2019 general election campaigns in Spain?

- $\quad$ Research Question 2: Was there any scheduling pattern as regards the Facebook ads posted by the main parties during the two 2019 general election campaigns in Spain?

- Research Question 3: What were the main topics, in terms of their estimated spend, addressed in the Facebook ads posted by the main parties during the two 2019 general election campaigns in Spain?

\section{Materials and Methods}

The main national parties leading the polls during the pre-campaigns and campaigns running up to the two general elections held in Spain in 2019 were the Spanish Socialist Workers' Party, the People's Party, Cs, Unidas Podemos, and Vox. Given that Unidas Podemos did not have its own account in the Facebook Ad Library in 2019, both Podemos and United Left were included for building the corpus, along with the rest of the parties with a national scope.

Facebook offers the option of requesting information about sponsored ads through its application programing interface (API). In 2019, however, only data on posted content could be obtained in this way, in sharp contrast to the information now available in the recently launched Facebook Ad Library. For this reason, a Python web scraper was coded to download information on the ads posted by the six selected Spanish parties during the two 2019 general election campaigns from the Facebook Ad Library. This information included the text and the image or video appearing in each ad, along with scheduling, spend, and number of impressions. Along with the availability of the data to explore the use of ads by political parties, we consider that this social network presents a central role to understand political communication on the Internet (Dyrby and Jensen 2012; Kalsnes 2016; Koc-Michalska et al. 2021).

The web scraper downloaded the ads for two periods: in May 2019 for the first campaign, and in November 2019 for the second campaign. We did not limit the sample to an specific target audience or cost. The corpus was finally made up of 14,684 Facebook ads (see Table 1).

Table 1. Number of ads, estimated impressions, and spend by party $(n=14,684)$. Source: Own elaboration.

\begin{tabular}{ccccc}
\hline Elections & $\begin{array}{c}\text { Number of } \\
\text { Ads }\end{array}$ & $\begin{array}{c}\text { Estimated } \\
\text { Spend (€) }\end{array}$ & $\begin{array}{c}\text { Estimated } \\
\text { Impressions }\end{array}$ \\
\hline 28A & 6098 & Citizens & \\
\hline $10 \mathrm{~N}$ & 2462 & 448,300 & $51,582,500$ \\
\hline Total & $\mathbf{8 5 6 0}$ & 135,800 & $\mathbf{1 8 , 8 5 4 , 0 0 0}$ \\
\hline & & United Left & $\mathbf{7 0 , 4 3 6 , 5 0 0}$ \\
\hline $28 \mathrm{~A}$ & 13 & & 4500 & $1,148,000$ \\
\hline $10 \mathrm{~N}$ & 5 & 250 & 59,500 \\
\hline Total & $\mathbf{1 8}$ & $\mathbf{4 7 5 0}$ & $\mathbf{1 , 2 0 7 , 5 0 0}$ \\
\hline
\end{tabular}


Table 1. Cont.

\begin{tabular}{|c|c|c|c|}
\hline Elections & $\begin{array}{c}\text { Number of } \\
\text { Ads }\end{array}$ & $\begin{array}{l}\text { Estimated } \\
\text { Spend }(€)\end{array}$ & $\begin{array}{c}\text { Estimated } \\
\text { Impressions }\end{array}$ \\
\hline \multicolumn{4}{|c|}{ People's Party } \\
\hline $28 \mathrm{~A}$ & 3609 & 442,850 & $57,295,000$ \\
\hline $10 \mathrm{~N}$ & 908 & 46,500 & $2,940,500$ \\
\hline Total & 4517 & 489,350 & $60,235,500$ \\
\hline \multicolumn{4}{|c|}{ Podemos } \\
\hline $28 \mathrm{~A}$ & 379 & 813,650 & $100,110,500$ \\
\hline $10 \mathrm{~N}$ & 545 & 181,450 & $29,881,500$ \\
\hline Total & 924 & 995,100 & $129,992,000$ \\
\hline \multicolumn{4}{|c|}{ Spanish Socialist Workers' Party } \\
\hline $28 \mathrm{~A}$ & 336 & 51,800 & $18,492,500$ \\
\hline $10 \mathrm{~N}$ & 285 & 17,550 & $4,275,000$ \\
\hline Total & 621 & 69,350 & $22,767,500$ \\
\hline \multicolumn{4}{|c|}{ Vox } \\
\hline $28 \mathrm{~A}$ & 0 & 0 & 0 \\
\hline $10 \mathrm{~N}$ & 44 & 2800 & 881,500 \\
\hline Total & 44 & 2800 & 881,500 \\
\hline \multicolumn{4}{|c|}{ TOTAL } \\
\hline $28 \mathrm{~A}$ & 10,435 & $1,761,100$ & $228,628,500$ \\
\hline $10 \mathrm{~N}$ & 4249 & 384,350 & $56,892,000$ \\
\hline Total & 14,684 & $2,145,450$ & $285,520,500$ \\
\hline
\end{tabular}

Notes: 28A = April 28, 2019, General elections; 10N = November 10, 2019, General elections.

To answer RQ1, two information sources were contrasted: the 2019 Facebook financial report and the study ad database. The inconvenience of this second source is that the Ad Library provides information on the spend and impressions of individual ads in numerical ranges. To resolve this problem, the ranges' midpoints were established as the numerical values for arriving at estimates in both cases. This approach was regarded as the best option, given that the Ad Library does not offer any further information on these variables.

Regarding RQ2, it was found that the corpus had a limitation. The Ad Library did not specify the last day of publication for all the ads in the corpus. Specifically, only 7566 out of the 14,684 ads included this information. Nevertheless, as this subsample accounted for roughly half of the corpus, the scheduling data available for the other ads were taken as a reliable estimate in this respect during both election campaigns.

Finally, as to RQ3, inquiring into the topics addressed by the parties in their Facebook ads, a content analysis was performed on the corpus to identify the main issues broached by the six parties during the two campaigns. A preliminary exploration of the dataset revealed that many ads repeated the same text and graphic elements. These ads conveyed an identical message, but differed in their metadata. In light of this, a content identifier was created to label the same messages included in different ads; a group that will be referred to here as visually identical ads (hereinafter VIAs). Since 1743 VIAs were identified in the corpus, the content analysis was performed on them and the results extrapolated to the 14,684-ad corpus. 
The categories for the content analysis were as follows: (1) party promotion; (2) pacts, coalitions, and surveys; (3) social policy; (4) economic policy; (5) international policy; (6) employment; (7) national unity (independence, the country's glorification); (8) feminism; (9) education and science; (10) environmental issues; (11) democratic quality (corruption); (12) depopulation of rural areas; (13) immigration; (14) infrastructure; and (15) others. Similar topics were employed for content analysis for social networks' topics in the 2019 elections in Spain (Pérez-Curiel and García-Gordillo 2020).

Two of the authors coded the VIA corpus (accounting for $10 \%$ of the 14,684 -ad corpus), while inter-rater reliability was assessed using Krippendorf's alpha, obtaining a value $(\alpha=0.904)$ higher than the typically accepted "rule of thumb" cutoff threshold $(\alpha=0.8)$ (Krippendorf 2013).

\section{Results}

\subsection{The Parties' Facebook ad Spend during the Two Election Campaigns}

According to the 14,684-ad corpus, the six Spanish parties spent more than $€ 2$ million on Facebook ads during the two 2019 election campaigns. In addition, it is estimated that this sponsored content generated more than 285 million impressions during both campaigns (Table 1). Parties spent $€ 7.05$ million on average on both campaigns (Calderón 2019a, 2019b), so that $28.57 \%$ of the budget was allocated on Facebook that year.

Two parties stood out in terms of ad creation and spend on Facebook. Citizens was the party that published the largest number of ads, totaling 8560 (58.29\% of the corpus), in both election campaigns, a figure doubling that of the party coming in second place (the People's Party, with 4517). However, this party did not have the highest spend, nor did its ads generate the greatest number of impressions, this being Podemos, with an estimated total spend of $€ 995,100$ and approximately 129,992,000 impressions.

Facebook provides data disaggregated by disclaimer in its financial report; so, it is possible for an organization to publish sponsored content under different labels. The top 10 ads with a "paid for by" disclaimer by-line in Facebook's 2019 financial report included six Spanish political parties: Podemos in first and second place, Citizens in third place, the People's Party in fourth place, and the Spanish Socialist Workers' Party in ninth and tenth place. In contrast, United Left and Vox were much lower down in the ranking, outside the top 100. The unequal cost of each ad explained why some parties (i.e., Podemos) published less sponsored content for a higher cost. Without delving further into the relation between prize and advertisements' characteristics, we observed that ads with the highest number of impressions coincided mainly with the most expensive ones.

The ranking in Table 2 allows identifying the parties' position in the list of greatest Facebook investors in Spain, proving they had an essential role in the advertisement incomes on this social network. Comparing the data retrieved from Facebook's 2019 financial report (see Table 2) with those contained in the study database, it can be seen that the proportion of ads published during the two election campaigns was approximately half of the total published throughout 2019 by the parties, except for United Left, all of whose ads were posted during the two campaigns. As to ad spend, however, the estimates provided here do not tally with the figures appearing in Facebook's 2019 financial report. This may be due to inaccuracies in the report, as claimed by Facebook, and/or to the estimates based on the data provided by the Facebook Ad Library. 
Table 2. Spanish political parties' ad spend on Facebook from January 2019 to January 2020. Source: Facebook Ad Library report (January 2019-January 2020).

\begin{tabular}{|c|c|c|c|c|c|}
\hline Position * & Page ID & Page Name & Disclaimer & Total Spend $(€)$ & No. of Ads in Library \\
\hline 1 & 269212336568846 & Podemos & Unidas Podemos & 635,976 & 1798 \\
\hline 2 & 269212336568846 & Podemos & Unidas Podemos & 611,601 & 373 \\
\hline 27 & 269212336568846 & Podemos & $\begin{array}{c}\text { Unidas Podemos } \\
\text { CAMBIAR EUROPA }\end{array}$ & 51,250 & 17 \\
\hline 47 & 269212336568846 & Podemos & Podemos & 23,339 & 43 \\
\hline 3 & 74078667754 & Cs & Cs & 493,142 & 17,622 \\
\hline 163 & 74078667754 & Cs & $\begin{array}{c}\text { Ads without a } \\
\text { disclaimer }\end{array}$ & 2846 & 9 \\
\hline 4 & 72249031214 & PP & PP & 413,526 & 11,172 \\
\hline 9 & 189318235003 & PSOE & PSOE & 122,783 & 1548 \\
\hline 10 & 189318235003 & PSOE & $\begin{array}{l}\text { Ads without a } \\
\text { disclaimer }\end{array}$ & 111,025 & 17 \\
\hline 123 & 74858103866 & $\mathrm{IU}$ & $\mathrm{IU}$ & 4388 & 19 \\
\hline 384 & 74858103866 & IU & $\begin{array}{l}\text { Ads without a } \\
\text { disclaimer }\end{array}$ & 632 & 3 \\
\hline 187 & 467127060059387 & VOX España & VOX & 2470 & 87 \\
\hline 700 & 467127060059387 & VOX España & $\begin{array}{l}\text { Ads without a } \\
\text { disclaimer }\end{array}$ & 286 & 14 \\
\hline
\end{tabular}

Notes: Cs = Citizens, $\mathrm{PP}=$ Peoples Party, PSOE $=$ Spanish Socialist Workers' Party, IU = United Left. ${ }^{*}$ Position in the rank of the advertisers that sponsored content in Facebook during 2019.

\subsection{Ad Scheduling}

The data available on scheduling patterns $(n=7566)$ indicate that both the number of ads and ad spend increased during the final days of the election campaigns (see Supplementary Data in Table S1). In some cases, daily spend tripled average spend. During the April 2019 election campaign, Citizens spent $€ 126,100$ (on 1692 ads) three days before polling day, the party's last round of ads during the campaign. Until then, it had spent an average of $€ 32,000$ per day (on 440 ads). Podemos was the only party to schedule ads during the pre-campaign and campaign periods, publishing the greatest number of ads per day $(115$ ads; $€ 213,200)$ five days before polling day, the highest figures before then being between 42 and 65 ads. The activity of its coalition partner, United Left, stands out precisely because it was the party with the lowest ad spend.

The People's Party reached its maximum daily spend ( $€ 200,700$ on 400 ads) three days before polling day, while publishing the greatest number of ads (866) the day before. The conservative party's ad scheduling and spend did not follow a regular pattern. For its part, the Spanish Socialist Workers' Party published very few ads in comparison with the rest of the parties, publishing the greatest number (88) a week before polling day. Additionally, as to daily spend, this was lower, with a maximum spend of $€ 10,300$ five days before polling day.

As a rule, the parties that actively employed the Facebook Ads platform during the April 2019 election campaign spent much less during the November campaign, although ad spend was still considerable. As to Citizens, it published the largest number of ads (962), coinciding with its maximum daily spend ( $€ 54,700)$, eight days before polling day. For its part, Podemos' ad spend peaked ( $€ 89,900$ on 171 ads) six days before polling day, compared with an average daily spend of $€ 5000$ ( 40 ads). Moreover, of the total number of ads published by this party during the November election campaign $(545), 125(€ 49,100)$ were scheduled to run outside the official campaign period. Its coalition partner, United Left, stood out for publishing the lowest number of ads (5) and for spending the least (€250). 
The People's Party only published five VIAs during the November campaign. The party spent $€ 14,250$ ( 285 ads) on one of these, which was scheduled to run eight days before polling day, whereas the most expensive cost $€ 30,300$ (604 ads) and was scheduled to run nine days before polling day-namely, the first day of the election campaign. It hardly published any new ads during the rest of the campaign. On the first day of the campaign, the Spanish Socialist Workers' Party spent $€ 10,900$ (178 ads), after which it maintained an average daily spend of $€ 1200$ euros ( 20 ads). The party also published seven ads (€350) on the day before the official campaign commenced.

Moving on to Vox, the party spent nothing on Facebook advertising during the April campaign, but did indeed in the November campaign, albeit with a modest budget of $€ 2800$. It warrants noting that 11 out of 44 ads $(€ 550)$ were published before the start of the official campaign. The remaining 33 ads (€2250) were posted together, three days before polling day.

Ad scheduling varied slightly from campaign to campaign. Whereas in the April campaign, most of the ads ran on average for between two and four days, in the November campaign, most of them ran for between two and seven days. The number of active ads also increased in the final days, but, surprisingly, 30 ads were scheduled before the start of the two-election campaign, thus contravening Spanish electoral law. Likewise, as shown in Figure 1, the April campaign was longer and, consequently, with a greater number of active ads per day.

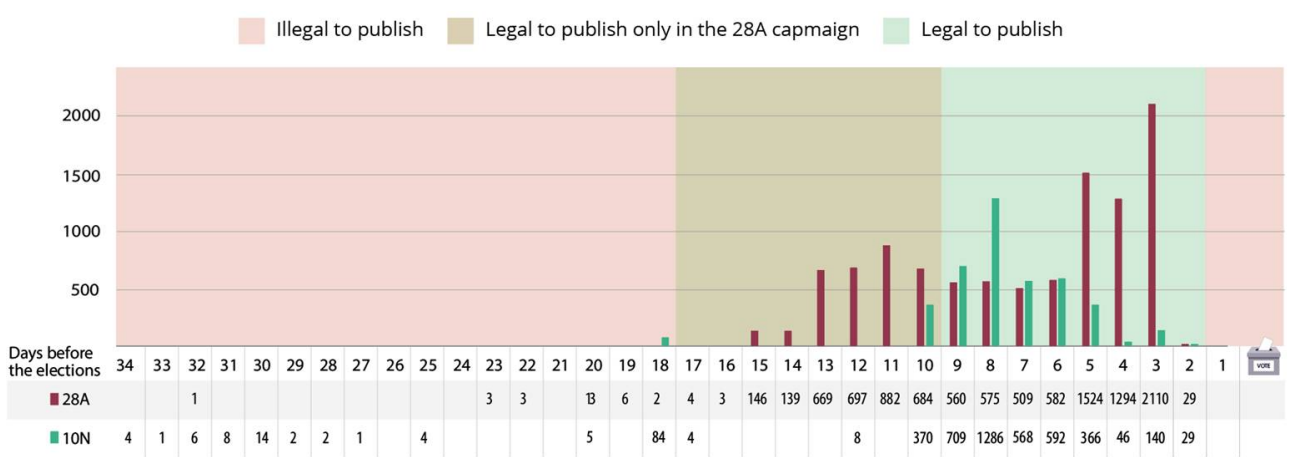

Figure 1. Ads published during the studied periods. Source: Own elaboration.

Figure 1 shows those ads contravening the law because they were published before the election campaigns had officially commenced. Specifically, these amounted to 545 ads (32 before the April election campaign and 513 before the November election campaign, accounting for $3.7 \%$ of the total corpus) at a total cost of $€ 197,650$ ( $€ 123,950$ for the April election campaign and $€ 73,700$ for the November election campaign).

\subsection{Content Analysis}

Table 3 shows the estimated cost of the Facebook ads published by the six Spanish parties during both 2019 election campaigns, distributed by topic. As can be clearly observed, party promotion was the dominant topic. As it accounted for more than a quarter of the estimated ad budget $(€ 615,750)$, it was also by far the topic on which the six Spanish parties made the greatest expenditure in both campaigns. The other topics on which they spent most in Facebook ads during both campaigns were employment $(€ 391,250)$, national unity $(€ 266,550)$ and economic policy $(€ 248,100)$. Although the accent was placed on party promotion in the May campaign (see Table 4), in the November campaign there was a shift towards more specific topics, including employment, economic policy, and feminism. 
Table 3. Estimated cost by topic of the Facebook ads published by the six Spanish parties in both 2019 election campaigns $(n=14,695)$. Source: Own elaboration.

\begin{tabular}{cc}
\hline Topic & Estimated Cost (€) \\
\hline Party promotion & 615,750 \\
\hline Employment & 391,250 \\
\hline National unity & 266,550 \\
\hline Economic policy & 248,100 \\
\hline Feminism & 140,250 \\
\hline Social policy & 125,050 \\
\hline Pacts, coalitions, and surveys & 94,850 \\
\hline Education and science & 81,950 \\
\hline Democratic quality & 69,050 \\
\hline Environmental issues & 63,100 \\
\hline Depopulation of rural areas & 18,450 \\
\hline Others & 18,250 \\
\hline International policy & 7400 \\
\hline Immigration & 3400 \\
\hline Infrastructure & 2050 \\
\hline Total & $\mathbf{2 , 1 4 5 , 4 5 0}$ \\
\hline
\end{tabular}

Table 4. Estimated cost by topic of the Facebook ads published by the six Spanish parties in both 2019 election campaigns $(n=14,695)$. Source: Own elaboration.

\begin{tabular}{|c|c|c|c|c|c|c|}
\hline Topic & Cs & United Left & People's Party & Podemos & $\begin{array}{l}\text { Spanish Socialist } \\
\text { Workers' Party }\end{array}$ & Total \\
\hline Party promotion & 127,250 & 2250 & 223,950 & 170,650 & 26,300 & 550,400 \\
\hline Employment & 7800 & 300 & 106,100 & 194,500 & 4050 & 312,750 \\
\hline National unity & 109,850 & & 40,400 & 78,400 & & 228,650 \\
\hline Economic policy & 29,700 & 1350 & 7750 & 129,150 & 2300 & 170,250 \\
\hline Social policy & 43,800 & & 14,050 & 49,800 & 1850 & 109,500 \\
\hline $\begin{array}{l}\text { Pacts, coalitions, } \\
\text { and surveys }\end{array}$ & 42,650 & 300 & 14,250 & 36,000 & & 93,200 \\
\hline Feminism & 23,900 & & 7050 & 33,450 & 4400 & 68,800 \\
\hline Democratic quality & 13,400 & & & 47,550 & & 60,950 \\
\hline Environmental issues & 10,050 & & 2300 & 46,550 & 1450 & 60,350 \\
\hline Education and science & 7950 & 300 & 16,800 & 27,600 & 5850 & 58,500 \\
\hline $\begin{array}{c}\text { Depopulation of rural } \\
\text { areas }\end{array}$ & 8550 & & 9650 & & & 18,200 \\
\hline Others & 15,850 & & 200 & & 1900 & 17,950 \\
\hline International policy & 6450 & & 300 & & 550 & 7300 \\
\hline Immigration & & & & & 3150 & 3150 \\
\hline Infrastructure & 1100 & & 50 & & & 1150 \\
\hline Total & 448,300 & 4500 & 442,850 & 813,650 & 51,800 & $1,761,100$ \\
\hline
\end{tabular}


The results by campaign and by party reveal different patterns (see Tables 4 and 5). There were significant lacunas in the topics covered by the six parties. Democratic quality was absent in the ads published by the People's Party in both campaigns and by the Spanish Socialist Workers' Party in the first one. Immigration was only addressed by the Spanish Socialist Workers' Party in the first campaign and only by Vox in the second one. Infrastructure was covered by Citizens and, to a much lesser extent, by the People's Party in the first campaign, and only by the Spanish Socialist Workers' Party in the second one. The depopulation of rural areas was monopolized by Citizens and the People's Party in the first campaign and by the Spanish Socialist Workers' Party in the second one.

Table 5. Ad spend by topic and party in the November election campaign $(n=4260)$. Source: Own elaboration.

\begin{tabular}{|c|c|c|c|c|c|c|c|}
\hline Topic & Cs & $\begin{array}{c}\text { United } \\
\text { Left }\end{array}$ & $\begin{array}{l}\text { People's } \\
\text { Party }\end{array}$ & Podemos & $\begin{array}{l}\text { Spanish Socialist } \\
\text { Workers' Party }\end{array}$ & Vox & Total \\
\hline Employment & 72,900 & & 2500 & 1300 & 1800 & & 78,500 \\
\hline Economic policy & 12,650 & & 6850 & 56,850 & 750 & 750 & 77,850 \\
\hline Feminism & & & & 69,550 & 1900 & & 71,450 \\
\hline Party promotion & 3300 & 200 & 29,500 & 25,000 & 6450 & 900 & 65,350 \\
\hline National unity & 9050 & & 2500 & 25,400 & 400 & 550 & 37,900 \\
\hline Education and science & 20,850 & & 2450 & & 150 & & 23,450 \\
\hline Social policy & 9550 & & 2550 & 750 & 2700 & & 15,550 \\
\hline Democratic quality & 7500 & & & 350 & 100 & 150 & 8100 \\
\hline Environmental issues & & & & 1600 & 1050 & 100 & 2750 \\
\hline $\begin{array}{l}\text { Pacts, coalitions, } \\
\text { and surveys }\end{array}$ & & 50 & 150 & 650 & 800 & & 1650 \\
\hline Infrastructure & & & & & 900 & & 900 \\
\hline Others & & & & & 200 & 100 & 300 \\
\hline Immigration & & & & & & 250 & 250 \\
\hline $\begin{array}{l}\text { Depopulation of } \\
\text { rural areas }\end{array}$ & & & & & 250 & & 250 \\
\hline International policy & & & & & 100 & & 100 \\
\hline Total & 135,800 & 250 & 46,500 & 181,450 & 17,550 & 2800 & 384,350 \\
\hline
\end{tabular}

As to the estimated ad spend of the six parties (see Tables 4 and 5), Citizens focused on party promotion ( $28 \%$ of its estimated budget) and national unity $(24 \%)$ in the first campaign, and on employment (54\%) and education and science (15\%) in the second one. The People's Party, for its part, placed the accent on party promotion (51\%) and employment $(24 \%)$ in the first campaign, whereas in the second it prioritized party promotion $(63 \%)$ and economic policy $(15 \%)$.

Podemos, the party with the highest estimated budget, spent more on ads addressing employment (24\%) and party promotion (21\%) during the first campaign, and feminism (38\%) and economic policy (31\%) during the second one. Whereas the Spanish Socialist Workers' Party focused on party promotion (51\%) and education and science (11\%) in the first campaign, and on party promotion (37\%) and social policy (15\%) in the second one. Lastly, Vox only invested in Facebook Ads in the second campaign, its main focus being party promotion (32\%) and social policy $(27 \%)$.

\section{Discussion}

Concerning Research Question 1, the results show that the ad spend of the six political parties during the two 2019 general election campaigns was uneven-from approximately $€ 3000$ to $€ 800,000$. In this respect, Podemos and the People's Party were the two parties 
that spent most on Facebook ads, as well as being two of the top advertisers on this social networking site during 2019 as a whole. In sum, Spain's political parties leveraged the communication opportunities that Facebook offered them during the two 2019 election campaigns, to the point of spending half of their Facebook budgets in these two periods.

So, it can be claimed that the six parties were fully aware of the commercial logic of this social networking site when including it in their political strategies. Even Podemos resorted to sponsored content for disseminating its messages, notwithstanding the fact that one of its founding principles was to strive for a more democratic use of the Internet (Gerbaudo 2019). Besides, the study results endorse Feenberg and Jin's (2015) reflections on Facebook's complex business model. The fact that political parties feature among this social networking site's best clients in election years is an important aspect for understanding its political resonance in contemporary politics.

As to Research Question 2, dealing with ad scheduling, most of the ads published by the six political parties appeared during the final days of both election campaigns and usually ran for two days. From these findings it can be deduced that the parties made a concerted effort to renew their online content and believed that the last days of the two election campaigns were critical for swaying undecided voters. Political ads are especially crucial when voting intentions are unclear - this might explain why ad spend during the April general election campaign was considerably higher than that during the shorter campaign in November. Additionally, none of the ads ran for the entire election campaigns, which suggests that the parties' strategy was perfectly adapted to digital content consumption on Facebook.

These findings have served to corroborate Ridout et al.'s (2021) words of warning about content sponsored by political parties before election campaigns, as well as confirming the contradiction between this global platform and local political processes (Sinclair 2016). Electoral law in Spain involves a number of restrictions. First and foremost, 545 ads were published before the two 2019 general election campaigns, despite the fact that it is illegal to publish sponsored content at times other than during the official campaign per $\mathrm{se}^{2}$. To this should be added that there is no law in Spain capping spend on publicly accessible social networking sites ${ }^{3}$, in contrast to other media for which there are indeed spending limits. Lastly, there is an urgent need to regulate the partisan use of the Internet in Spain. Otherwise, political parties will continue to have a powerful digital tool at their disposal which helps them to circumvent the legislation in force.

Moving on to Research Question 3, inquiring into the issues broached by the six political parties in their Facebook ads, the results reveal the difference in Facebook usage from one country to another. While Ridout et al. (2021) have focused on message goals, this variable is pointless in Spain, where political parties avoid using certain techniques (e.g., signing petitions, requesting donations, administering surveys, etc.) for engaging the electorate. Quite to the contrary, since they have maintained vertical communication practices, the information and communication technology revolution has not been accompanied by transformative political strategies. Neither Podemos nor Cs, the parties that brought an end to the country's two-party system (Boix Palop and García 2014), innovated in this regard. Future research may analyze the equivalence of ads and campaign themes on political leaders' Facebook profiles.

The dominant topic during the two campaigns was party promotion. Specifically, this issue was more prevalent in the first campaign, maybe because it was planned in a more conventional way. The fact that the general elections had to be repeated in November after the failure to form a government might explain why the sponsored content published by the parties on Facebook was much more focused on economic and social issues than on party promotion.

Leaving aside party promotion, which is a common aspect of any electoral advertising strategy, the majority of the topics addressed in the Facebook ads were very closely related to Spain's political context, marked by economic instability, the pro-independence challenge in Catalonia, and the rise of the feminist movement (Orriols and Cordero 2016; 
Simón 2020). The country's political parties broached these issues, while connecting them to their agendas. Employment was a major topic in both campaigns, in terms of Facebook ad spend. A number of surprising strategies were also pinpointed. For instance, Podemos was the party that paid most attention to this issue in the first campaign ( $€ 194,500$ out of $€ 813,650)$, while in the following one this topic hardly got a look in ( $€ 1300$ out of $€ 181,450)$. A similar pattern can be identified in the People's Party's Facebook ad strategy in this respect ( $€ 106,100$ out of $€ 442,850$ in April, and $€ 2500$ out of $€ 46,500$ in November). Citizens spent much less on ads addressing this topic ( $€ 7800$ out of $€ 448,300$ in April, and $€ 72,900$ out of $€ 135,800$ in November). And, lastly, employment was of capital importance for the Spanish Socialist Workers' Party ( $€ 4050$ out of $€ 51,800$ in April, and $€ 1800$ out of $€ 17,550$ in November). In the first three cases, the parties shifted their attention abruptly, most probably due to their perception of the burning issues debated between both general elections. In order to qualify these findings, however, closer attention should be paid to the way in which this topic was framed and presented by each party.

In light of the importance given to national unity, a topic ranking in third place in the April election campaign and in fifth in the following one in November in terms of ad spend, it can be concluded that the issue of Catalan independence formed part of the parties' Facebook ad strategies. In the first campaign, Citizens was the party that spent most on ads addressing this topic ( $€ 109,850$ out of $€ 448,300)$, while in the second campaign Podemos led the field ( $€ 25,400$ out of $€ 813,650)$. Considering that national unity has traditionally been a central issue for $\mathrm{Cs}$, it was reasonable to expect that it would have been one of the mainstays of its advertising strategy. Be that as it may, Citizens spent much less on ads revolving around this issue ( $€ 9050$ out of $€ 135,800$ ). Podemos' stance on national unity in the November campaign might have been related to the situation in Catalonia, but, then again, it might have been influenced by the rise of Vox, a party for which it is of utmost importance.

The topic of feminism was addressed in the April campaign by all the parties, except for United Left, with the two newcomers Podemos ( $€ 33,450$ out of $€ 813,650)$ and Citizens ( $€ 23,900$ out of $€ 448,300)$ spending most on ads in this respect. Nevertheless, in the following campaign this topic was practically monopolized by Podemos $(€ 69,550$ out of $€ 181,450)$.

In the main, the parties reflected their main concerns, besides promoting themselves, in their online advertising strategies on Facebook. As the putative heir to the 15-M movement, Podemos paid more attention to feminism and democratic quality (Domínguez and Giménez 2014). Citizens highlighted topics more related to Spain and democratic quality, as a way of distancing itself from its mainstream adversaries. The People's Party focused more on economic policy and the Spanish Socialist Workers' Party on several issues relating to social policies. Lastly, as already noted, Vox made little use of this advertising channel.

The academic literature on political communication has been paying increasingly more attention to organic content on Facebook, at the expense of the sponsored kind. This study has underscored the need for further inquiry into Facebook Ad Library content for three main reasons. Firstly, political parties are important ad-based content providers, an aspect that should be borne in mind when studying the political facet of social media and the relationship between political organizations and tech corporations (Haenschen and Wolf 2019; Sinclair 2016).

Secondly, Facebook is a digital platform whose functionalities do not necessarily adapt to a particular context. As a result, it did not prevent Spain's political parties from publishing content classified as illegal in its electoral law. The possibility of circumventing domestic legislation may help to reinforce the Internet as a political communication and campaign arena. This issue is of crucial importance for meeting recent challenges for democracy, such as the use of the Internet for spreading disinformation (Mustafaraj and Metaxas 2017).

Finally, Facebook allows for making comparisons between different political scenarios. During the two 2019 general election campaigns in Spain, recent developments influenced 
the online advertising strategies of the six parties analyzed here, which gives rise to two considerations. Political strategy ultimately depends on the democratic traditions of the country in question, and the Facebook Ad Library has opened up a new avenue for comparative research on different elections and countries. However, to this should be added that political parties wield greater power on social media when they are able to include their messages in users' newsfeeds. If Facebook were to transform the digital social space into a commodified space (Corbett 2014), then those actors with more economic resources would be able to maintain an advantageous position and, consequently, to gain greater visibility. Facebook Ad Library is thus a useful tool for studying political strategies and connecting the behavior of parties to broader reflections on the state of democracy in contemporary times.

This study has two main limitations. On the one hand, the analysis of electoral advertising was limited to the Facebook ads published by the national parties with the greatest election expectations, whereby the ads published by their regional branches or by other political parties were not considered. In view of the fact that those branches have a lot to say in national politics, the conclusions arrived at here cannot be extrapolated to the Spanish political landscape as a whole. Likewise, ad spend was solely based on information provided by Facebook, so any additional costs involved in producing audio-visual content or implementing online campaign strategies were not taken into account.

On the other, it is important to stress the platform's structural constraints, which have been previously highlighted by Edelson et al. (2020) and Silva et al. (2020). Regarding the monetary and audience targeting variables, the data provided by the Facebook Ad Library are simplified and not very accurate, as they are based on numerical ranges. Furthermore, nor does the Facebook annual report provide detailed data on the ad spend of political parties because it aggregates them.

The release of the Facebook Ad Library has opened up promising avenues for research and for auditing the ad spend and strategies of political parties. One way of gaining deeper insights into the topics addressed in digital advertising would be to supplement content analyses with adequate qualitative analyses. This approach could be very helpful for identifying the different ways in which each party frames the same topic. Another future line of research could be to correlate the microtargeting information provided by the Facebook Ad Library with the other metadata, such as ad spend and impressions or, even more importantly, with ad content and images.

\section{Conclusions}

Social networking sites, such as Facebook, form a digital space for sharing usergenerated content and interacting with other users. It can be claimed that this global platform is permeated by a commercial logic, for its business model consists precisely in "selling" this social space to advertisers. The massive amount of data collected by Facebook enable it to offer organizations effective tools for reaching target audiences in a very selective manner. Due to its huge user base, advertising generates significant revenues for the company. In this context, election campaigns have become a relevant source of revenue for Facebook (Bakir and McStay 2018; Haenschen and Wolf 2019; Kreiss and McGregor 2018). The fact that political parties advertise on this social networking site, which holds the promise of becoming a lively digital public space (Dahlgren 2005), means that, driven by the profits that it can reap from this activity, it now runs the risk of being inundated by carefully crafted political messages aimed at specific user profiles. This should prompt the citizenry and researchers to scrutinize this communication channel in an attempt to disentangle the political messages embedded in its newsfeeds.

Leveraging the Facebook Ad Library, launched in May 2018, we have inquired into the global trend of political advertising on Facebook. We have studied the use of this powerful marketing tool by the main Spanish political parties during the two campaigns running up to the general elections held in May and November 2019, which has allowed us to detect several issues worth considering in other campaigns. First and foremost, there is the 
existing gap between the legislation on political advertising on mainstream media and the absence of supervision on social networking sites, a concern already raised by Ridout et al. (2021). Thanks to the Facebook Ad Library, it is now possible to detect infractions, such as the publication of political ads before campaigns commence, and to scrutinize the ad spend and sponsored content of political parties on Facebook during electoral campaigns. This sort of scrutiny is of value to both political communication researchers and society at large. As we have shown here, mining this rich information source has brought to light the different strategies implemented by the six Spanish parties in the two election campaigns. Our analysis has not been limited to the sponsored content per se, but has also focused on ad spend, which has allowed us to single out the most important topics. In turn, this has raised several questions that merit further inquiry. At least in Spain there is no law capping spend on social networking sites by political parties. Given that there are restrictions for other media, there should be a public debate on this issue, even more so since political parties figure among Facebook's top advertisers.

Facebook has also become an essential political communication channel. It is a social space that not only allows politicians, like any other user, to post their thoughts and updates with the aim of interacting with their follower base (Ceccobelli 2018), but also to disseminate their messages to selected profiles via sponsored content, like any other advertiser. The electorate should become more familiar with the power of the Facebook Ad platform. Democracy demands transparency from this advertising channel, and the launching of the Facebook Ad Library has been a welcome first step in the right direction. However, more steps should be taken. As we have proposed here, the possibility of auditing ad impact, spend and target audiences are promising possibilities for consolidating a healthier digital social space.

Supplementary Materials: The following are available online at https:/ / www.mdpi.com/article/10 $.3390 /$ socsci10070271/s1, Table S1: Periodic expenditure and publication during the days leading up to the elections.

Author Contributions: D.C. has written the theoretical part. L.C.-O. has produced the results. T.B. has extracted the research corpus for the article. All authors have participated in the revision of the article and in the final conclusions. All authors have read and agreed to the published version of the manuscript.

Funding: This research has been carried out in the framework of the project entitled "Strategies, agendas and discourse in electoral cybercampaigns: media and citizens" (CSO2016-77331-C2-1-R), of the research group Mediaflows.

Institutional Review Board Statement: Not applicable.

Informed Consent Statement: Not applicable.

Data Availability Statement: Data of this research can be found at: http://hdl.handle.net/10251/14 6502. Please cite it as follows: “Baviera Puig, T. (2020). 2019 Spanish General Elections Facebook Ads Dataset. https:/ / doi.org/10.4995/Dataset/10251/146502".

Acknowledgments: The authors are grateful to Exponentia CIO Juan Besari for his valuable help in the data-extraction processes.

Conflicts of Interest: The authors declare no conflict of interest.

\section{Notes}

1 Specifically, the affairs that led to the no-confidence vote were the proved facts of a parallel accounting system of undeclared donations coordinated by Luis Bárcenas, former Peoples' Party's treasurer. In this turn of events, it also played a major role the ongoing investigation of the Kitchen affair, an alleged operation of the Ministry of the Interior to steal sensitive information from the same ex-treasurer.

2 The maximum duration of an election campaign is 15 days and election silence lasts $24 \mathrm{~h}$ before polling day. Both aspects are regulated by Organic Law 5/1985, of 19 June 1985, on the general electoral system. 
3 Neither Law 19/2013, of 9 December, on transparency, access to public information and good governance, nor Organic Law $3 / 2015$, of 30 March, on the control of the economic and financial activity of political parties.

\section{References}

Bakir, Vian, and Andrew McStay. 2018. Fake News and The Economy of Emotions: Problems, causes, solutions. Digital Journalism 6: 154-75. [CrossRef]

Bennett, Colin, and Jesse Gordon. 2020. Understanding the "Micro" in Micro-Targeting: An Analysis of Facebook Digital Advertising in the 2019 Federal Canadian Election. SSRN. [CrossRef]

Boix Palop, Andrés, and Guillermo López García López García. 2014. El significado de las Elecciones Europeas de 2014 en España: Giro a la izquierda y hundimiento del bipartidismo. Unión Europea Aranzadi 7: 69-93.

Broockman, David E., and Donald P. Green. 2014. Do online advertisements increase political candidates' name recognition or favorability? Evidence from randomized field experiments. Political Behavior 36: 263-89. [CrossRef]

Calderón, Inés. 2019a. ¿Cuánto se han gastado los partidos en la campaña del 28-A? Newtral. Available online: https:/ / www.newtral. es/cuanto-se-han-gastado-los-partidos-en-la-campana-del-28-a/20190425/ (accessed on 10 July 2021).

Calderón, Inés. 2019b. Los gastos de los partidos en la campaña del 10 de noviembre. Newtral. Available online: https: / / www.newtral. es/los-gastos-de-los-partidos-en-la-campana-del-10-de-noviembre/20191103 (accessed on 10 July 2021).

Campos-Domínguez, Eva, and Berta García-Orosa. 2018. Comunicación algorítmica en los partidos políticos: Automatización de producción y circulación de mensajes. Profesional de la Información 27: 769-77. [CrossRef]

Cano-Orón, Lorena, Dafne Calvo, Guillermo López García, and Tomás Baviera. 2021. Disinformation in Facebook Ads in the 2019 Spanish General Election Campaigns. Media and Communication 9: 217-28. [CrossRef]

Carratalá, Adolfo, and Dolors Palau-Sampio. 2019. Between activism and mediatization: Parties and media's frames in the Catalan campaign of 2017. Revista de Comunicación. [CrossRef]

Ceccobelli, Diego. 2018. Not every day is Election Day: A comparative analysis of eighteen election campaigns on Facebook. Journal of Information Technology \& Politics 15: 122-41. [CrossRef]

Corbett, Steven. 2014. Challenging the commodification of public spheres: The hacker work ethic in a free media lab. First Monday 19. [CrossRef]

Dader, José Luis, and Eva Campos-Domínguez, eds. 2017. La Búsqueda Digital del Voto. Cibercampañas Electorales en España 2015-16. Valencia: Tirant lo Blanch.

Dahlgren, Peter. 2005. The Internet, public spheres, and political communication: Dispersion and deliberation. Political Communication 22: 147-62. [CrossRef]

Domínguez, Ana, and Luis Giménez. 2014. Claro que Podemos. De La Tuerka a la esperanza del cambio en España. Barcelona: Los Libros del Lince.

Dommett, Katharine, and Sam Power. 2019. The political economy of Facebook advertising: Election spending, regulation and targeting online. Political Quarterly 90. [CrossRef]

Doyle, Kim. 2015. Facebook, Whatsapp and the commodification of affective labour. Communication, Politics and Culture 48: 51-65.

Dyrby, Signe, and Tina Blegind Jensen. 2012. Exploring Affordances of Social Media Use in Election Campaigns: What Political Parties Want to Facilitate, Project and Create. In Proceedings of the 2012 Pre-ICIS Workshop, Orlando, FL, USA, December 4.

Edelson, Laura, Tobias Lauinger, and Damon McCoy. 2020. A security analysis of the Facebook ad library. In Proceedings of the IEEE Symposium on Security and Privacy. New York, NY, USA, May 18-21. [CrossRef]

Feenberg, Andrew, and Dal Yong Jin. 2015. Commodity and community in social networking: Marx and the monetization of user-generated content. The Information Society: An International Journal 31: 52-60. [CrossRef]

Fuchs, Christian. 2016. Critical Theory of Communication: New Readings of Lukács, Adorno, Marcuse, Honneth and Habermas in the Age of the Internet. London: University of Westminster Press. [CrossRef]

Gerbaudo, Paolo. 2019. The Digital Party. London: Pluto Press.

Gray, Jonathan, Liliana Bounegru, and Tommaso Venturini. 2020. 'Fake news' as infrastructural uncanny. New Media and Society 22: 317-41. [CrossRef]

Haenschen, Katherine, and Jordan Wolf. 2019. Disclaiming responsibility: How platforms deadlocked the Federal Election Commission's efforts to regulate digital political advertising. Telecommunications Policy 43: 101824. [CrossRef]

Isaak, Jim, and Mina J. Hanna. 2018. User data privacy: Facebook, Cambridge Analytica, and privacy protection. Computer 51: 56-59. [CrossRef]

Kalsnes, Bente. 2016. The Social Media Paradox Explained: Comparing Political Parties' Facebook Strategy Versus Practice. Social Media + Society 2. [CrossRef]

Karpf, David. 2016. Analytic Activism: Digital listening and the New Political Strategy. Oxford: Oxford University Press.

Karpf, David. 2018. Analytic activism and its limitations. Social Media + Society 4. [CrossRef]

Kim, Young Mie, Jordan Hsu, David Neiman, Colin Kou, Levi Bankston, Soo Yun Kim, Richard Heinrich, Robyn Baragwanath, and Garvesh Raskutti. 2018. The stealth media? Groups and targets behind divisive issue campaigns on Facebook. Political Communication 35: 515-41. [CrossRef] 
Koc-Michalska, Karolina, Darren G. Lilleker, Tomasz Michalski, Rachel Gibson, and Jan M. Zajac. 2021. Facebook affordances and citizen engagement during elections: European political parties and their benefit from online strategies? Journal of Information Technology \& Politics 18: 180-93. [CrossRef]

Kosinski, Michael, David Stillwell, and Thore Graepel. 2013. Private traits and attributes are predictable from digital records of human behavior. Proceedings of the National Academy of Sciences of the United States of America 110: 5802-5. [CrossRef] [PubMed]

Kreiss, Daniel, and Shannon C. McGregor. 2018. Technology firms shape political communication: The work of Microsoft, Facebook, Twitter, and Google with campaigns during the 2016 US presidential cycle. Political Communication 35: 155-77. [CrossRef]

Krippendorf, Klaus. 2013. Content Analysis: An Introduction to its Methodology. Thousand Oaks: Sage.

López-García, Guillermo, and Lidia Valera-Ordaz, eds. 2017. Pantallas Electorales: El discurso de partidos, medios y ciudadanos en la campaña de 2015. Barcelona: UOC.

Moore, Martin. 2016. Facebook, the Conservatives and the Risk to Fair and Open Elections in the UK. Political Quarterly 87: 424-30. [CrossRef]

Mustafaraj, Eni, and Panagiotis Takis Metaxas. 2017. The Fake News Spreading Plague: Was it Preventable? Paper presented at 2017 ACM Web Science Conference, New York, NY, USA, June 27.

Orriols, Lluis, and Guillermo Cordero. 2016. The Breakdown of the Spanish Two-Party System: The Upsurge of Podemos and Ciudadanos in the 2015 General Election. South European Society and Politics 21: 469-92. [CrossRef]

Pérez-Curiel, Concha, and Mar García-Gordillo. 2020. Del debate electoral en TV al ciberdebate en Twitter. Encuadres de influencia en las elecciones generales en España (28A). Profesional de la información. [CrossRef]

Pérez-Curiel, Concha, Gloria Jiménez-Marín, and Marta Pulido-Polo. 2021. Corrupción política, liderazgo e influencia en Twitter. Un análisis sobre la transparencia pública en el marco de las elecciones del 28 de abril en España. Mediterranean Journal of Communication 12: 209-26. [CrossRef]

Plantin, Jean-Christophe, Carl Lagoze, Paul N. Edwards, and Christian Sandvig. 2018. Infrastructure studies meet platform studies in the age of Google and Facebook. New Media + Society 20: 293-310. [CrossRef]

Richterich, Annika. 2018. How data-driven research fuelled the Cambridge Analytica controversy. Partecipazione e conflitto 11: 528-43. [CrossRef]

Ridout, Travis N., Erika Franklin Fowler, and Michael M. Franz. 2021. The Influence of Goals and Timing: How Campaigns Deploy Ads on Facebook. Journal of Information Technology and Politics. [CrossRef]

Rodon, Toni. 2020. The Spanish electoral cycle of 2019: A tale of two countries. West European Politics 43: 1490-512. [CrossRef]

Rossini, Patricia, Jennifer Stromer-Galley, Kate Kenski, Jeff Hemsley, Feifei Zhang, and Brian Dobreski. 2018. The relationship between race competitiveness, standing in the polls, and social media communication strategies during the 2014 U.S. gubernatorial campaigns. Journal of Information Technology and Politics 15: 245-61. [CrossRef]

Silva, Márcio;, Lucas Santos De Oliveira, Athanasios Andreou, Pedro Olmo Vaz De Melo, Oana Goga, and Fabricio Benevenuto. 2020. Facebook Ads Monitor: An Independent Auditing System for Political Ads on Facebook. Paper presented at Web Conference 2020, New York, NY, USA, April. [CrossRef]

Simón, Pablo. 2020. The Multiple Spanish Elections of April and May 2019: The Impact of Territorial and Left-right Polarisation. South European Society and Politics. [CrossRef]

Simón, Pablo. 2021. Two-bloc Logic, Polarisation and Coalition Government: The November 2019 General Election in Spain. South European Society and Politics. [CrossRef]

Sinclair, John. 2016. Advertising and media in the age of the algorithm. International Journal of Communication 10: $3522-35$.

Tandoc, Edson C., Zheng Wei Lim, and Richard Ling. 2018. Defining "Fake News": A typology of scholarly definitions. Digital Journalism 6: 137-53. [CrossRef]

Tuttle, Hilary. 2018. Facebook scandal raises data privacy concerns. Risk Management 65: 6-9.

Youyou, Wu, Michaiel Kosinski, and David Stillwell. 2015. Computer-based personality judgments are more accurate than those made by humans. Proceedings of the National Academy of Sciences of the United States of America 112: 1036-40. [CrossRef] 